\title{
Digital library: An Innovation in Infrastructure in Learning and Development amongst Students
}

\author{
Prof. Devrshi Upadhayay \\ Faculty of Management, GLS University, Ahmedabad, India
}

\begin{abstract}
Web distributed network system made extension for inquire about in the territory of data framework and its related fields. Advanced Library, one of the latest improvements in Library and Information Science, which help its client to look for data through internet browser. Computerized Library is sorted out grouping of data, with its bolstered administrations and a spot where the data is kept in advanced arrangement and can be recovered over a system. Since most recent multi decade specialists are concentrating on the clients of Digital Library to grow progressively proficient and viable framework to offer quality assistance to clients. The point of this paper is to furnish writing on Digital Library as for its clients that might be useful for future research. The paper examines about the users driven methodology with regards to Digital Library.
\end{abstract}

Key words: Digital library, user centric approach, digital library, innovations in infrastructure

\section{Introduction}

Significant changes seen by society through the transmission of information around the globe and it is accountable to the evolution of information technology. Now it is possible to archiving and accessing knowledge in the digitized form besides preservation of traditional knowledge due to use of information technology. Demand for electronic information increasing day by day and at the same time traditional format of library becoming more and more expensive and complex to maintain. Now it is time for libraries to capitalize these challenges and meet demands and expectations of digital users. Libraries has to redesign their services to create value addition to satisfy the user's community.

\section{II.Literature Review}

This section of the article discusses about the research related to user's experience with digital library. This may be helpful to understand user's opinion, attitude, satisfaction and service experiences with digital library which can be further considered for enhancing user's satisfaction towards the use of digital library.

Ekere et al (2016) study the perception of users towards digital library facilities, resources and services and found that users are highly satisfied with it. Users are highly aware and satisfied about the digital library resources such and WWW, WIFI and search engines compare to online databases, portals, online abstract, video CDs, CD-ROMs, and online indexes and abstract.
Asad Khan (2016) investigated the factors that influence the adoption of Digital Library among research students. The findings revealed that Interface characteristics influence cognitive response which predict student's intention of using digital library. Whereas navigation, individual differences and system characteristics significantly affected the ease of use. Usefulness is directly affected by system characteristics and system quality. Finally, it is found that usefulness have highest effects on digital library usage intention.

Xianjin et al (2015) worked on Flow experience with respect to Mobile Library and try to compares perception of user's with mobile libraries and web digital libraries with respect to flow experience. Where flow experience defined as best experience about an activity that can be done by comparing perceived skills and perceived challenges. Study reveals that more users experienced flow in using web digital libraries than mobile libraries.

Yuangen and Zeng (2014) worked with customer churn rate and it is the rate of customer discontinuation with digital library service. Study found that customer churn rate of the given library is very high and same with churn hazard in initial three months after customer's registration on the web site of the library.

Xianjin et al (2014) investigated the effects of user's perception towards print and digital resources in terms of usage, usefulness and ease of use. There is a significant effect of the characteristics of user's such as gender, age field and experience on perception of users with respect to usefulness, usage and ease of use. 
Yalan et al (2014) examined quality of digital library which define as the quality of information quality of system and overall service quality of digital library. The compression of user's perceptions towards virtual communities and digital libraries have been done understand the actual nature of $\mathrm{e}$ quality perceived by the users. Based on the user's perception study found that digital libraries provide better information, system and service quality than virtual communities.

Ahmed (2013) study the usage pattern of digital information resources and satisfaction with university resources by the faculty members. It is found that faculty members are dissatisfied with current e-resources by the university. Service related issues are the main reason for dissatisfaction such as limited title and access to past issues, They identified limited number of titles, limited access to back issues, difficulty in finding information, inability to access from home, limited access to computers and slow download speed as major constraints. However, poor infrastructure and limited access to these resources is the main reason for dissatisfaction.

Chang (2013) study user's behavior intention towards using mobile library application by applying unified theory of acceptance and usage of technology (UTAUT) with task technology fit model. Effort expectancy, social influence, facilitating conditions and performance expectancy influence the behavioral intention towards mobile library application. Task technology model have moderating effect on behavioral intention.

Ming-der et al (2012) research scholar are frequent users of digital resources of library in this regard this study investigated usage pattern, search behavior of graduate students and perception towards digital resources. Study reveals that students are using digital resources during thesis writing and science and technology student consider it as the most important for their research compare to other disciplines. Less number of students are using metasearch and alter services to collect update information.

Lorraine Paterson and Boon Low, (2011) found that students has higher acceptance of mobile library services.

Anna (2008) indicated that user's perception is defer by the institute to institute and the services they offered. Further, users have positive attitude towards digital library but at the same time most of them are unaware about various services offered by the digital library. It is also found that interface considered to be an important factor to use digital library.

Nov and Ye (2008) employed technology acceptance model and support that TAM has explanatory power to predict intention. This study found that resistance to change is the important determinant of perceived ease of use.
Nor et al (2006) users have positive perception towards wireless application in the context of library and information services and most of the users responded affirmatively to be a part of wireless services if offered.

Enrique (2005) reveals that the satisfaction with respect to digital library is still the area in which improvement required. A more deep study shows that from a Cognitive style perspective, Intermediate users are satisfied with the interface, but in Filed Dependency and Field Independency, users expects some improvements, especially help to operate the system. This is also true from a gender approach, where females are more dissatisfied than males, mainly because of the lack of help. Finally it is found that as level of expertise increases the user's satisfaction is decreases.

\section{Conceptual framework}

Digital Library is a source that rebuild the knowledge and supports of conventional library in digital form. Digital Library is organized assortment of information, with its supported services and a place where the information is kept in digital format and can be retrieved over a networks. It comprise of digital contents which interconnected by establishing link, metadata or simply query based relationship and software which may use basic pages in HTML or based on database management system. It can be interpreted on the basis of above definition that a single web page or huge collection mass digital information is not a digital library. Here, it is important to note that digital libraries are not going to replace conventional libraries but rather digital libraries are the future of conventional libraries (Seadle, 2007). Basically, digital library is required technological support to link the resources of many services that are disseminated to user. Collection of information is not restricted to document storage but it is extended to digital artefacts than can only be distributed in digital formats.

Digital library resources are like other library materials in many ways. They are selected, acquired, cataloged, managed, explained and promoted to users, evaluated, preserved, withdrawn and cancelled. Digital information resources include journals, government documents electronic images etc. Digital information exists in a format (numeric digits) that computer can store, organize, transmit and display without any intervening conversion process.

The digital resources are available on various digital medias such as CD Rom, DVDS, floppies, online databases, digital archives, etc. Electronic information Resources contain originally published information in digital form information. It is originally published in print form and then made available electronically. Among resources, E-journals and e-books are mostly in demands by the users. 
In early 70s most of the electronic resources were available in magnetic tapes and other magnetic media. But today various types of resources are available and accessed are intranet online (locally produced e-resources) and physical media (stored-data on CD-Rom, audio, video cassettes etc) based creation of digital resources with the establishment of digital library is the need of the day. The digital information resources are going to play most vital role in the 21 st century. The rapid developments in information technology have facilitated the emergence of new electronic devices, media and formats.

The major function of digital libraries is to facilitate systematic and efficient access to and sharing of information of matters, considered important by the users. Not only does digital libraries promotes resources sharing, but also in the long run it can help in sharing of knowledge and resources.

Some on line libraries or information centers have started collecting a nominal fee for access their resources. As they are well-connected and networked with provide specialized subject information.

\section{Digital / E- Library Resources}

An electronic resources means the publication and dissemination of information by electronic means, especially by the use optical disk -formats such as CD ROMs and networking. Other option can include the use of electronic databases, videotexes, e-mail, and electronic newsletter.

A digital library may refer only to electronic resources or means combinations of electronic resources, services that via a network. In simple terms, e-resources are those resources, which require computer access or any electronic product. That delivers a collection of data, be it text referring to full text databases, electronic journals, image collections, other multimedia products and numerical, graphical or time-based, as a commercially available little that has been published with an aim to being marketed.

\section{A. Digital Library resources includes}

- Collection in which complete contents documents are created or converted in Machine-readable form for online access

- Scientific data sets

- Scanned images, images of photographic or printed text etc.

- Computer storage devices' such as optical disk, CDROMs/ DVD- ROMs

- Databases accessible through internet and other networks
- $\quad$ Online databases and CD-ROM information products particularly those with multimedia and interactive video components

\section{B. Advantages of Digital Library Resources}

Electronic resources offer libraries and their uses many advantages. There are several advantages of using e-resources such as case of - usability, affordability and accessibility. They can increase speed and case to access and the amount of information available.

They can save library space and staff time. They are not yet, however, the solution to all libraries financial, space, access and service problem. Most libraries continue to operate in a dual environment - print and electronic resources, whether physically located within a library or accessed via a network, are part of the library's collection and should be evaluated and assessed with the same criteria and rigor applied to all collection decisions.

\section{Why Need Digital Library Resources?}

Due to the increase in the information generation the task of collection, organization and retrieval of information made the task very difficult. That is why most of the libraries perfect electronic resources to print collection for optimum use. The other reason are physical space, escalation in journals prices, digital literacy has forced the libraries to opt for electronic resources in order to meet information needs of large community of users.

Digital library can store a large volume of digital information in archival form. A digital library may refer only to electronic resources or mean a combination of electronic resources, services that support using those resources or mean a combination of electronic resources, services that are provided via a network. It provides the users fast search tools, immediate access to the rapidly growing information in multimedia form quickly on the screen in an interactive mode.

\section{Types of Digital Library Resources}

- Online e-resources

- E-journals (Full text and E- Book)

- Online databases

- Websites

Other types of e-resources Other e-resources which are available digital media such as;

- CD-Rom

- Diskettes

- Other portable databases 


\section{V.Research Methodology}

Research methodology covers how research is carried out in this paper:

- Research design: Descriptive design

- Source of data: Primary and Secondary data

- Primary data tool: Structured questionnaire

- Secondary data tool: Web articles and journals

- Sample size: 100 Students from social science courses such as (Commerce, Arts, Management and Humanities)

\section{Research objectives:}

1. To understand the scenario of E-learning and conceptual framework for Digital library in India.

2. To know the perspective of student for utilization and accessibility of Digital library in their learning and development process.

VII. Results and Findings

\begin{tabular}{|c|c|c|c|c|c|}
\hline \multicolumn{6}{|c|}{ Gender * Using Digital Library * UG/PG Crosstabulation } \\
\hline \multicolumn{6}{|c|}{ Count } \\
\hline \multirow{2}{*}{\multicolumn{3}{|c|}{ UG/PG }} & \multicolumn{2}{|c|}{ Using Digital Library } & \multirow[t]{2}{*}{ Total } \\
\hline & & & Yes & No & \\
\hline \multirow{3}{*}{ UG } & \multirow{2}{*}{ Gender } & Male & 23 & 30 & 53 \\
\hline & & Female & 0 & 3 & 3 \\
\hline & \multicolumn{2}{|c|}{ Total } & 23 & 33 & 56 \\
\hline \multirow{3}{*}{ PG } & \multirow{2}{*}{ Gender } & Male & 1 & 6 & 7 \\
\hline & & Female & 2 & 31 & 33 \\
\hline & \multicolumn{2}{|c|}{ Total } & 3 & 37 & 40 \\
\hline \multirow{3}{*}{ Total } & \multirow{2}{*}{ Gender } & Male & 24 & 36 & 60 \\
\hline & & Female & 2 & 34 & 36 \\
\hline & \multicolumn{2}{|c|}{ Total } & 26 & 70 & 96 \\
\hline
\end{tabular}

From above cross tabulation of Gender, Using digital library and UG/PG course depicts that out of 96 students 70 students responded that they don't use digital library and out of 70 respondents there were 33 students were from UG course.

\begin{tabular}{|l|c|c|c|}
\hline \multicolumn{4}{|c|}{ Descriptive Statistics } \\
\hline & $\mathrm{N}$ & Mean & Std. Deviation \\
\hline Using Digital Library & 96 & 1.73 & .447 \\
\hline Why Not using Digital Library & 70 & 2.67 & 1.059 \\
\hline If Yes (Frequency of using) & 26 & 2.54 & 1.140 \\
\hline Purpose of using Digital library & 26 & 2.23 & .652 \\
\hline Influence by whom ? & 26 & 1.65 & .485 \\
\hline Valid N (listwise) & 0 & & \\
\hline
\end{tabular}

Above frequency table shows for various aspects of digital library and all aspects were calculated with mean to analyze in more effective and to justify the frequency and also above all various aspects there are more than 70 students are not using
82801001202005

digital library, the mean of not using digital library is 2.67 that means lack of infrastructure and lack of demo and user manual is also one of the criteria for selecting and using digital library. There were 26 students are using digital library and purpose of using digital library differ from one to one but mean score suggest that purpose of using digital library is twice/thrice in semester and once in a month.

\begin{tabular}{|c|c|c|c|c|c|c|c|}
\hline \multicolumn{8}{|c|}{ Gender * Why Not using Digital Library * UG/PG Crosstabulation } \\
\hline \multirow{3}{*}{\multicolumn{3}{|c|}{ UG/PG }} & & Count & & & \multirow[b]{3}{*}{ Total } \\
\hline & & & \multicolumn{4}{|c|}{ Why Not using Digital Library } & \\
\hline & & & $\begin{array}{c}\text { Lack } \\
\text { of }\end{array}$ & Lack of & Lack of & $\begin{array}{l}\text { Not } \\
\end{array}$ & \\
\hline \multirow{3}{*}{ Male } & \multirow[b]{2}{*}{ Gender } & Male & 8 & 7 & 9 & 6 & 30 \\
\hline & & Female & 0 & 1 & 2 & 0 & 3 \\
\hline & \multicolumn{2}{|c|}{ Total } & 8 & 8 & 11 & 6 & 33 \\
\hline \multirow{4}{*}{ PG } & \multirow{2}{*}{ Gender } & Male & 1 & 3 & 1 & 1 & 6 \\
\hline & & Female & 3 & 7 & 9 & 12 & 31 \\
\hline & \multicolumn{2}{|c|}{ Total } & 4 & 10 & 10 & 13 & 37 \\
\hline & \multicolumn{2}{|c|}{ Total } & 12 & 18 & 21 & 19 & 70 \\
\hline
\end{tabular}


[5]. Asad Khan Saima Qutab , (2016),"Understanding research students' behavioural intention in the adoption of digital libraries A Pakistani perspective ", Library Review, Vol. 65 Iss 4/5 pp. 295 - 319 Permanent link to this document: http://dx.doi.org/10.1108/LR-06-2015-0070

[6]. Chang Chiao-Chen , (2013)," Library mobile applications in university libraries ", Library Hi Tech, Vol. 31 Iss 3 pp. 478 - 492 Permanent link to this document: http://dx.doi.org/10.1108/LHT-03-20130024

[7]. Ekere, Justina n. dr.; omekwu, charles obiora; and nwoha, chidinma m. (2016), "User's perception of the facilities, resources and services of the MTN digital library at the university

[8]. Lorraine Paterson Boon Low, (2011),"Student attitudes towards mobile library services for smartphones", Library Hi Tech, Vol. 29 Iss 3 pp. 412 - 423 Permanent link to this document: http://dx.doi.org/10.1108/07378831111174387

[9]. Ming-der Wu Shih-chuan Chen, (2012),"How graduate students perceive, use, and manage electronic resources", Aslib Proceedings, Vol. 64 Iss 6 pp. $641-$ 652 Permanent link to this document: http://dx.doi.org/10.1108/00012531211281779

[10]. Michael Seadle and Elke Greifeneder, (2007), "Defining a digital library" Library Hi Tech Vol. 25 No. 2, 2007 pp. 169-173 Permanent link to this document: DOI 10.1108/07378830710754938

[11]. Nor Shahriza Abdul Karim Siti Hawa Darus Ramlah Hussin, (2006),"Mobile phone applications in academic library services: a students' feedback survey", Campus-Wide Systems, Vol. 23 Iss 1 pp. 35 - 51 Permanent link to this document: http://dx.doi.org/10.1108/10650740610639723

[12]. Nigeria, nsukka" (2016). Library philosophy and practice (e-journal). 1390 http://digitalcommons.unl.edu/libphilprac/1390

[13]. Oded Nov and Chen Ye (2008), User's Personality and Perceived Ease of Use of Digital Libraries: The Case for Resistance to Change, journal of the American society for information science and technology, 59(5):845-851 Permanent link to this document: DOI: 10.1002/asi.20800

[14]. Michael Seadle, Elke Greifeneder (2007) "Defining a digital library", Library Hi Tech, Vol. 25 Iss: 2, pp.169 $-173$

[15]. S.M. Zabed Ahmed, (2013),"Use of electronic resources by the faculty members in diverse public universities in Bangladesh", The Electronic Library,
Vol. 31 Iss 3 pp. 290 - 312 Permanent link to this document: http://dx.doi.org/10.1108/EL-05-20110081

[16]. Xianjin Zha Jinchao Zhang Yalan Yan Wentao Wang , (2015)," Comparing flow experience in using digital libraries Web and mobile context ", Library Hi Tech, Vol. 33 Iss 1 pp. 41 - 53, available at: http://dx.doi.org/10.1108/LHT-12-2014-0111

[17]. Xianjin Zha Jinchao Zhang Yalan Yan , (2014)," Exploring the effect of individual differences on user perceptions of print and electronic resources ", Library Hi Tech, Vol. 32 Iss 2 pp. 346 - 367 Permanent link to this document: http://dx.doi.org/10.1108/LHT-072013-0099

[18]. Ying-Hung Pu Po-Sheng Chiu Tzung-Shi Chen Yueh-Min Huang , (2015)," The design and implementation of a Mobile Library APP system ", Library Hi Tech, Vol. 33 Iss 1 pp. 15 - 31 Permanent link to this document: http://dx.doi.org/10.1108/LHT10-2014-0100. 